\title{
Forskolin Inhibits Lipopolysaccharide-Induced Modulation of MCP-1 and GPR120 in 3T3-L1 Adipocytes through an Inhibition of NF $\kappa$ B
}

\author{
Jeanne Durendale Chiadak, ${ }^{1,2}$ Tatjana Arsenijevic, ${ }^{1}$ Kevin Verstrepen, ${ }^{1}$ \\ Françoise Gregoire, ${ }^{1}$ Nargis Bolaky, ${ }^{1}$ Valérie Delforge, ${ }^{1}$ Véronique Flamand, ${ }^{3}$ \\ Jason Perret, ${ }^{1}$ and Christine Delporte ${ }^{1}$ \\ ${ }^{1}$ Laboratory of Pathophysiological and Nutritional Biochemistry, Université Libre de Bruxelles, Brussels, Belgium \\ ${ }^{2}$ Department of Biochemistry, Faculty of Sciences, University of Dschang, Dschang, Cameroon \\ ${ }^{3}$ Institute for Medical Immunology, Faculty of Medicine, Université Libre de Bruxelles, Gosselies, Belgium
}

Correspondence should be addressed to Christine Delporte; cdelport@ulb.ac.be

Received 13 June 2016; Accepted 13 October 2016

Academic Editor: Julio Galvez

Copyright (C) 2016 Jeanne Durendale Chiadak et al. This is an open access article distributed under the Creative Commons Attribution License, which permits unrestricted use, distribution, and reproduction in any medium, provided the original work is properly cited.

\begin{abstract}
In an obese state, Toll-like receptor-4 (TLR-4) upregulates proinflammatory adipokines secretion including monocyte chemotactic protein-1 (MCP-1) in adipose tissue. In contrast, G-protein coupled receptor 120 (GPR120) mediates antiobesity effects. The aim of this study was to determine the signaling pathway by which Forskolin (FK), a cyclic adenosine monophosphate- (cAMP-) promoting agent causing positive changes in body composition in overweight and obese adult men, affects MCP-1 and GPR120 expression during an inflammatory response induced by lipopolysaccharide (LPS) in adipocytes, such as in an obese state. 3T3L1 cells differentiated into adipocytes (DC) were stimulated with LPS in the absence or presence of FK and inhibitors of TLR-4 and inhibitor of kappa B (I $\kappa \mathrm{B} \alpha)$. In DC, LPS increased MCP-1, TLR-4, and nuclear factor- $\kappa \mathrm{B} 1(\mathrm{NF} \kappa \mathrm{B} 1)$ mRNA levels, whereas it decreased GPR120 mRNA levels. In DC, FK inhibited the LPS-induced increase in MCP-1, TLR-4, and NF $\kappa$ B1 mRNA levels and the LPS-induced decrease in GPR120 mRNA. BAY11-7082 and CLI-095 abolished these LPS-induced effects. In conclusion, FK inhibits LPS-induced increase in MCP-1 mRNA levels and decrease in GPR120 mRNA levels in adipocytes and may be a potential treatment for inflammation in obesity. Furthermore, TLR-4-induced activation of NF $\kappa$ B may be involved in the LPS-induced regulation of these genes.
\end{abstract}

\section{Introduction}

In addition to storing excess energy, adipose tissue is now widely recognized as an important endocrine organ. Indeed, it secretes numerous cytokines called "adipokines" which have various functions, including macrophage recruitment, regulation of feeding behavior, energy homeostasis, and insulin sensitivity [1]. Obesity is characterized by adipose tissue inflammation and macrophage infiltration [2-4]. Adipose tissue expression of monocyte chemotactic protein-1 (MCP-1) and circulating MCP-1 levels are increased upon obesity in rodent, suggesting that MCP-1-mediated macrophage infiltration of adipose tissue may contribute to the metabolic disequilibrium associated with obesity and insulin resistance $[5,6]$. Evidence providing an inflammatory link between obesity and type 2 diabetes is accumulating. In numerous animal and clinical studies, obesity is associated with a state of low-grade, chronic inflammation in liver and adipose tissue, which includes activation of the innate immune system and the appearance of proinflammatory immune cells $[7,8]$. Nutritional strategies designed to alleviate adipokines dysregulation include modulating dietary fatty acids, with the majority of evidence suggesting the antiinflammatory effects of the marine derived long-chain n3 polyunsaturated fatty acids (PUFA) eicosapentaenoic acid (20:5n-3, EPA) and docosahexaenoic acid (22:6n-3, DHA) 
which can blunt lipopolysaccharide- (LPS-) stimulated elevations in adipokines [9-13]. Furthermore, activation of Gprotein coupled receptor 120 (GPR120) by DHA antagonizes the proinflammatory effects of tumor necrosis factors-alpha (TNF- $\alpha$ ) and lipopolysaccharide in a macrophage cell line [14]. The inhibitory effects of DHA on LPS-Toll-like receptor4- (TLR-4-) induced activation of nuclear factor-kappa B (NFkB) activity $[15,16]$ might be mediated by a GPR120 and $\beta$-Arrestin 2-dependent mechanism [14]. $\beta$-Arrestin proteins play an important role in regulating the responsiveness of G-protein coupled receptors (GPCRs) by contributing to mechanisms involved in both GPCR desensitization and resensitization [17].

Previous studies suggest that saturated fatty acids promote inflammation by activating TLR- 4 on adipocytes and macrophages [18]. Indeed, mice lacking TLR-4 are protected against high-fat diet-induced obesity, inflammation, and insulin resistance because they are resistant to the suppression of insulin signaling during lipid infusion and exhibit reduced insulin-mediated changes in systemic glucose metabolism [19]. Forskolin (FK) is a labdane diterpene, isolated from the roots of the Coleus forskohlii plant, a perennial herb with fleshy fibrous roots belonging to the mint family of plants. In the early-to-mid-1980s, Forskolin was primarily used as an agent to help a number of cardiovascular disease conditions, mainly through a vasodilator effect [20]. This effect resulted from increased adenylate cyclase activity within the body. Forskolin causes positive changes in body composition in overweight and obese adult men [21]. One of the potential explanations for the decrease in fat mass and body fat percentage may be adenylate cyclase activation and, thus, cyclic adenosine monophosphate (cAMP) accumulation within adipose tissue, which stimulates free fatty acid release and lipolysis. Indeed, Forskolin has been widely used as a potent activator of adenylate cyclase in cellular preparations to study cAMP-dependent transduction pathways [22-25]. As circulating MCP-1 levels are increased in rodent obesity and the role of Forskolin in fat mass reduction is clearly established, the aim of this study was to determine on one hand the expression of MCP-1, TLR4, GPR120, $\beta$-Arrestin 2, and NF $\kappa$ B1 expression in DC and on the other hand the signaling pathway by which Forskolin affects MCP-1 and GPR120 expression in the LPS-induced inflammatory response in 3T3-L1 cells differentiated into adipocytes.

\section{Materials and Methods}

2.1. Reagents. Dulbecco's modified Eagle's medium (DMEM, $4.5 \mathrm{~g} / \mathrm{L}$ glucose), streptomycin/penicillin, fetal bovine serum, horse serum, and calf serum were provided by Invitrogen (Carlsbad, CA, USA). Bovine insulin, 3-isobutyl-1-methylxanthine (IBMX), dexamethasone, lipopolysaccharides, and Forskolin were purchased from Sigma (St. Louis, MO, USA). TLR-4 signaling inhibitor (CLI-095) and kappa B (I $\kappa \mathrm{B} \alpha)$ inhibitor (BAY11-7082) were purchased from InvivoGen (San Diego, CA, USA). Anti- $\beta$-actin and anti-I $\kappa \mathrm{B} \alpha$ came from Millipore (Temecula, CA, USA), and anti-phospho-I $\kappa \mathrm{B} \alpha$
(Ser32/36) (5A5) was purchased from Cell Signaling Technology, Inc. (Danvers, MA, USA).

2.2. Cell Culture and Treatments. 3T3-L1 murine preadipocyte cells were grown in DMEM supplemented with $10 \%$ calf serum, $200 \mathrm{U} / \mathrm{mL}$ penicillin, and $200 \mathrm{U} / \mathrm{mL}$ streptomycin in $8 \% \mathrm{CO}_{2}$ humidified atmosphere at $37^{\circ} \mathrm{C}$ until confluence. Two days after confluence, to induce adipocyte differentiation, cells were incubated for $60 \mathrm{~h}$ in DMEM supplemented with $10 \%$ fetal bovine serum and containing $500 \mu \mathrm{M}$ IBMX, $0.25 \mu \mathrm{M}$ dexamethasone, and $10 \mu \mathrm{g} / \mathrm{mL}$ insulin. The cells were then maintained in the culture medium supplemented with insulin only and this media was changed every 2 days (day 5 and day 7) until complete differentiation (monitored by lipid droplet accumulation under the microscope and confirmed by Oil Red Coloration) had occurred (day 9). On day 9, the differentiated 3T3-L1 cells (DC) were treated for $4 \mathrm{~h}$ with water followed by $4 \mathrm{~h}$ with water and ethanol (CTL) or $4 \mathrm{~h}$ with water and $4 \mathrm{~h}$ with $10 \mu \mathrm{M}$ Forskolin (FK) or $4 \mathrm{~h}$ with $1 \mu \mathrm{g} / \mathrm{mL}$ LPS followed by $4 \mathrm{~h}$ with LPS and ethanol (LPS) or $4 \mathrm{~h}$ with LPS followed by $4 \mathrm{~h}$ LPS and FK (LPS + FK). Both cells and culture media from cultured undifferentiated cells (UDC; at day 0) and from DC (at day 9 following treatment) were harvested. To determine how the expressions of the genes of interest are modulated by $\mathrm{NF} \kappa \mathrm{B}$ activation, the $\mathrm{DC}$ were treated with $\mathrm{I} \kappa \mathrm{B} \alpha$ inhibitor BAY11-7082 at $10 \mu \mathrm{M}$. The TLR-4 signaling inhibitor CLI-095 at $3 \mu \mathrm{M}$ was also used. For inhibitor studies, DC were pretreated with the inhibitor for 1 hour before exposure to LPS stimulation and then coincubated with LPS and the inhibitor for $4 \mathrm{~h}$ prior to RNA extraction and $24 \mathrm{~h}$ prior to protein extraction.

2.3. RNA Isolation. Isolation of RNA, as well as assessment of RNA concentration and purity, and RNA integrity were performed as previously described [26, 27].

2.4. RT-qPCR. Design of $\mathrm{qPCR}$ primers, cDNA synthesis, and qPCR reactions were performed as previously described [26]. The primer pairs which were used are shown in Table 1.

2.5. Analysis of Gene Expression Stability. Gene expression stability analysis and matching statistics were performed using Biogazelle qBASE Plus software [28]. Data were normalized using the references genes, tyrosine 3-monooxygenase/tryptophan 5-monooxygenase activation protein, zeta polypeptide (mmYwhaz), non-POU-domain containing octamer binding protein ( $\mathrm{mmNONO}$ ), and $\beta$-actin (mmACTB), which were previously validated for this cellular and experimental system [26].

2.6. MCP-1 ELISA Assay. MCP-1 protein levels of the culture media were determined by ELISA using a Duoset ELISA kit from R\&D Diagnostics (Minneapolis, MN, USA).

2.7. Protein Extraction and Western Blot Analysis. DC were washed with calcium- and magnesium-free PBS and lysed in $1 \mathrm{~mL}$ of lysis buffer containing $50 \mathrm{mM}$ Tris/ $\mathrm{HCl}$ ( $\mathrm{pH}$ 7.5), $150 \mathrm{mM} \mathrm{NaCl}, 0.5 \%$ Nonidet P40, $50 \mathrm{mM} \mathrm{NaF}, 1 \mathrm{mM}$ 
TABLE 1: Real-time PCR primer sequences.

\begin{tabular}{lcc}
\hline Gene & Forward primer $\left(5^{\prime} \Rightarrow 3^{\prime}\right)$ & Reverse primer $\left(5^{\prime} \Rightarrow 3^{\prime}\right)$ \\
\hline mmNONO & TGCTCCTGTGCCACCTGGTACTC & CCGGAGCTGGACGGTTGAATGC \\
mmACTB & CCTGTGCTGCTCACCGAGGC & GACCCCGTCTCCGGAGTCCATC \\
mmYwhaz & AAAAACAGCTTTCGATGAAGCC & GCCGGTTAATTTCCCCTCC \\
mmMCP-1 & TTCACCAGCAAGATGATCCCA & TCCTTCTTGGGGTCAGCACA \\
mmTLR- 4 & AGGACTCTGATCATGGCACTG & GGAATGTCATCAGGGACTTTGC \\
mmGPR 120 & GGTGCCGGGACTGGTCATTGT & AGAGCGTGCGGAAGAGTCGGT \\
mm $\beta$-Arrestin 2 & ATGGGAGAAAAACCCGGGAC & CACAGGGTCCACTTTGTCCA \\
mmN $\kappa$ B 1 & CTGCAGCTCTTACCCTGGAG & GTAATTGCGTGGCAGAGTGG \\
\hline
\end{tabular}

sodium orthovanadate, dithiothreitol, and a cocktail of protease inhibitors (cOmplete EDTA-free, Roche). Whole cell lysates were prepared and submitted to SDS-polyacrylamide gel electrophoresis (SDS-PAGE) in the presence of $5 \% \beta$ mercaptoethanol using $12 \%$ polyacrylamide gels. Harvest of DC and preparation of whole cell lysates were performed as previously described [27]. Proteins were transferred to polyvinylidene difluoride membranes and immunolabeled using primary antibodies against $\mathrm{I} \kappa \mathrm{B} \alpha$, phospho-I $\kappa \mathrm{B} \alpha$, and $\beta$-actin. The bound primary antibodies were detected using secondary anti-mouse or anti-rabbit antibodies (GE Healthcare, Little Chalfont, Buckinghamshire, UK) and ECL chemiluminescence detection kit (PerkinElmer, Waltham, MA, USA). The protein bands were scanned and digitized, and the density of each band was determined using the Quantity One software (Bio-Rad Laboratories, Hercules, CA, USA).

2.8. Statistical Analysis. Data are presented as mean \pm SEM of 3 experiments. Group means were compared by paired $t$ test and $t$-test for unique sample. Differences were considered statistically significant at $p<0.05$. All statistical analyses were performed using SPSS 22 (IBM Corp. version 22.0.0.0).

\section{Results}

3.1. Expression of MCP-1, TLR-4, GPR120, and $\beta$-Arrestin 2 mRNA Levels in UDC and DC. MCP-1, TLR-4, GPR120, and $\beta$-Arrestin 2 mRNA levels were measured by RT-qPCR in UDC and DC. Upon adipocyte differentiation, TLR-4, GPR120, and $\beta$-Arrestin 2 mRNA levels were significantly upregulated 5-fold ( $p<0.05$ ), 130-fold ( $p<0.005$ ), and 1.6 -fold $(p<0.05)$, respectively (Figure 1$)$. In contrast, MCP1 mRNA levels were significantly downregulated 0.08 -fold $(p<0.005)$ upon adipocyte differentiation (Figure 1$)$.

3.2. Effect of FK and LPS Modulation of MCP-1 $m R N A$ and Protein Levels in DC. In DC, LPS significantly upregulated both mRNA (40-fold; Figure 2(a)) and protein (12.8-fold, Figure 2(b)) levels of MCP-1 $(p<0.05)$, as compared to CTL. In DC, FK did not significantly modify both MCP-1 mRNA and protein levels as compared to CTL (Figure 2). Upon treatment of DC with both LPS and FK, the MCP-1 mRNA level was significantly decreased by $95.7 \%$ as compared to LPS-treated DC $(p<0.05$, Figure 2(a)). However, MCP-1 protein level was not significantly modified under LPS and FK treatment as compared to LPS treatment alone at the time points assessed (Figure 2(b)).

3.3. Effect of FK and LPS on TLR-4 mRNA Levels in DC. LPS significantly increased TLR-4 mRNA level (1.6-fold) as compared to CTL $(p<0.05)$, while FK significantly decreased it (0.5-fold; $p<0.05)$ (Figure 3). TLR-4 mRNA level was significantly decreased by $73.5 \%$ in response to LPS and FK treatment as compared to LPS treatment $(p<0.05)$ (Figure 3).

3.4. Effect of FK and LPS on GPR120 mRNA Levels in DC. LPS significantly decreased GPR120 mRNA level (0.6-fold) as compared to CTL $(p<0.05)$, while FK significantly increased it (2.2-fold; $p<0.05)$ (Figure 4). LPS and FK significantly increased 2.8-fold the GPR120 mRNA level as compared to LPS treatment $(p<0.01)$ (Figure 4$)$.

3.5. Effect of FK and LPS on $\beta$-Arrestin $2 \mathrm{mRNA}$ in DC. LPS had no effect on $\beta$-Arrestin 2 mRNA level, whereas FK treatment significantly decreased it $(0.6$-fold; $p<0.05)$ (Figure 5$)$. In addition, $\beta$-Arrestin 2 mRNA level was not significantly modified under LPS and FK treatment as compared to that of LPS treatment alone (Figure 5).

3.6. Effects of LPS and FK on NFKB1 $m R N A$ and $I \kappa B \alpha$ Protein Levels in DC. LPS have been shown to stimulate secretion of inflammatory adipokines through activation of Toll-like receptor-4 (TLR-4) and the downstream transcription factor nuclear factor, $\mathrm{NF} \kappa \mathrm{B}$, in adipocytes [29-31]. In addition, a small increase in cytosolic concentrations of $\mathrm{I} \kappa \mathrm{B} \alpha$ negatively affects $\mathrm{NF} \kappa \mathrm{B}$ nuclear translocation [32]. We therefore examined the effect of LPS and FK on NF $\kappa$ B1 mRNA levels and $\mathrm{I} \kappa \mathrm{B} \alpha$ protein levels in $\mathrm{DC}$ and the result shows that the NF $\kappa$ B1 mRNA level was significantly upregulated in the presence of LPS as compared to CTL $(p<0.05)$. FK significantly decreased by $87.5 \%$ the $\mathrm{NF} \kappa \mathrm{B} 1 \mathrm{mRNA}$ level as compared to that of LPS-treated DC $(p<0.05)$ (Figure 6(a)). To determine if Forskolin affected $\mathrm{I} \kappa \mathrm{B} \alpha$ proteolysis and thereby $\mathrm{NF} \kappa \mathrm{B} 1$ activation, total and phosphorylated $\mathrm{I} \kappa \mathrm{B} \alpha$ protein levels were analyzed by semiquantitative Western blotting (Figures 6(b) and 6(c)). In DC treated with and without LPS in the presence or absence of Forskolin, no 


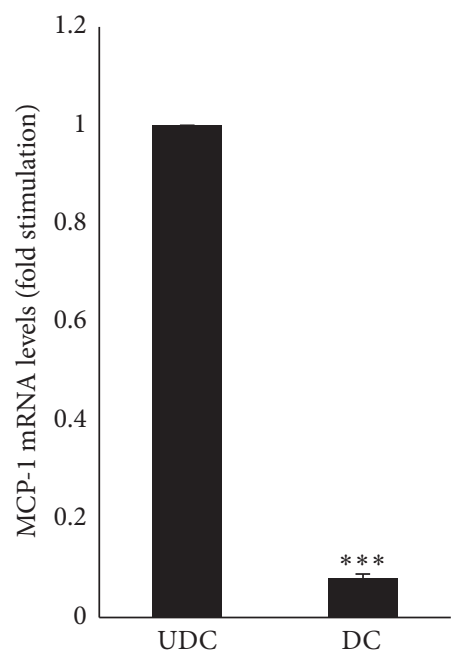

(a)

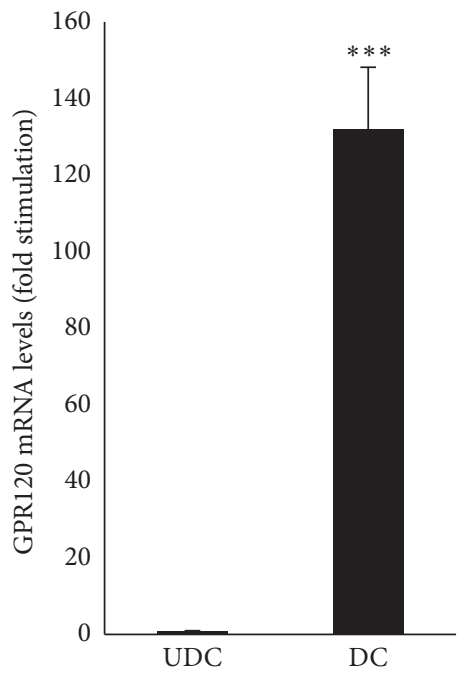

(c)

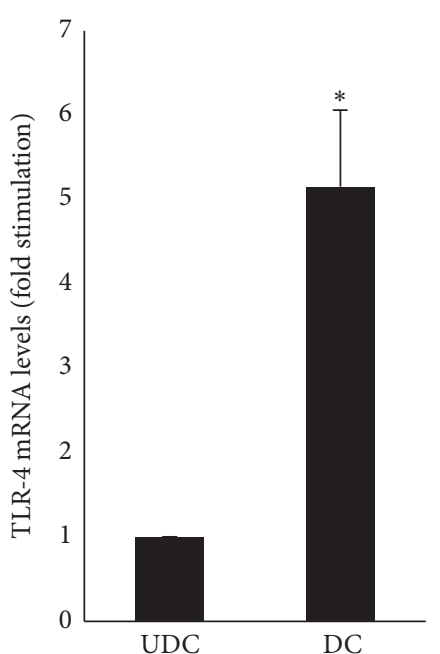

(b)

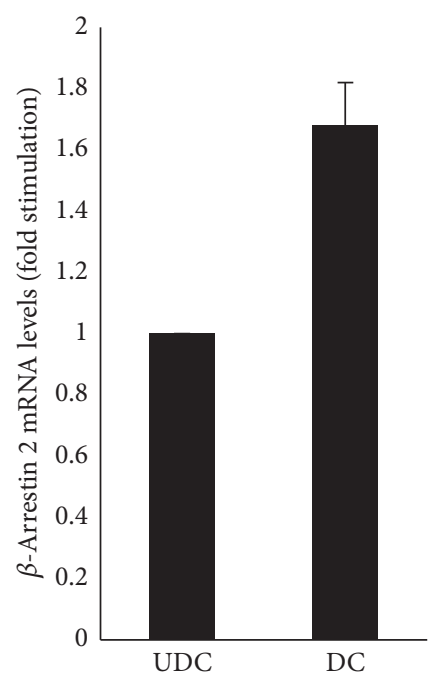

(d)

FIGURE 1: Expression of mRNA of MCP-1 (a), TLR-4 (b), GPR120 (c), and $\beta$-Arrestin 2 (d) in undifferentiated versus differentiated 3T3-L1 cells. UDC and DC were obtained as described under Materials and Methods. The results are expressed as relative mRNA levels (fold stimulation over UDC set to 1 ) and are the means \pm SEM of 3 independent experiments. Data were analyzed by $t$-test for unique sample; ${ }^{*} p<0.05$ and ${ }^{* * *} p<0.005$ versus UDC.

significant differences were observed in terms of $\mathrm{I} \kappa \mathrm{B} \alpha$ (total and phosphorylated) protein level (Figures 6(b) and 6(c)).

3.7. Effects of a TLR-4 Inhibitor on MCP-1, GPR120, TLR-4, and NFKB1 mRNA Levels upon LPS Treatment. To determine whether the regulation of MCP-1, GPR-120, and TLR-4 mRNA levels induced by LPS was mediated by TLR-4, a LPS receptor, DC were preincubated for 1 hour in the absence or presence of a TLR-4 inhibitor ( $3 \mu \mathrm{M}$ of CLI095) prior to a $4 \mathrm{~h}$ treatment with LPS $(1 \mu \mathrm{g} / \mathrm{mL})$. The MCP-1 mRNA level was significantly increased by LPS (80-fold; $p<0.05$ ) as compared to CTL, while CLI095 significantly decreased it by 80\% $(p<0.05)$ (Figure 7). LPS decreased the GPR120 mRNA (0.6-fold; $p<0.05)$ as compared to CTL, while CLI095 abolished it $(p<0.05)$ (Figure 7). In addition, both TLR4 and $\mathrm{NF} \kappa \mathrm{B} 1 \mathrm{mRNA}$ levels were significantly upregulated upon LPS treatment (3-fold and 2-fold, resp.; $p<0.05$ ) as compared to CTL, but they were abolished in the presence of CLI095 (Figure 7).

3.8. Effects of an I $\kappa B \alpha$ Inhibitor on MCP-1, GPR120, TLR-4, and NFKB1 mRNA Levels upon LPS Treatment. To specifically assess the involvement of an NFK $\mathrm{B} 1$-dependent pathway in the regulation of MCP-1 and GPR120 mRNA levels induced by LPS, DC were pretreated with an I $\kappa \mathrm{B} \alpha$ inhibitor, BAY117082, prior to LPS treatment. The LPS-induced increase in MCP-1 mRNA level was significantly decreased by $54 \%$ by BAY11-7082 $(p<0.05)$ (Figure 7). The LPS-induced decrease in GPR120 mRNA level was abolished by BAY11-7082 $(p<$ 0.05 ) (Figure 7). LPS-induced increase in both TLR-4 and $\mathrm{NF} \kappa \mathrm{B} 1 \mathrm{mRNA}$ levels was abolished in the presence of BAY117082 (Figure 7). 


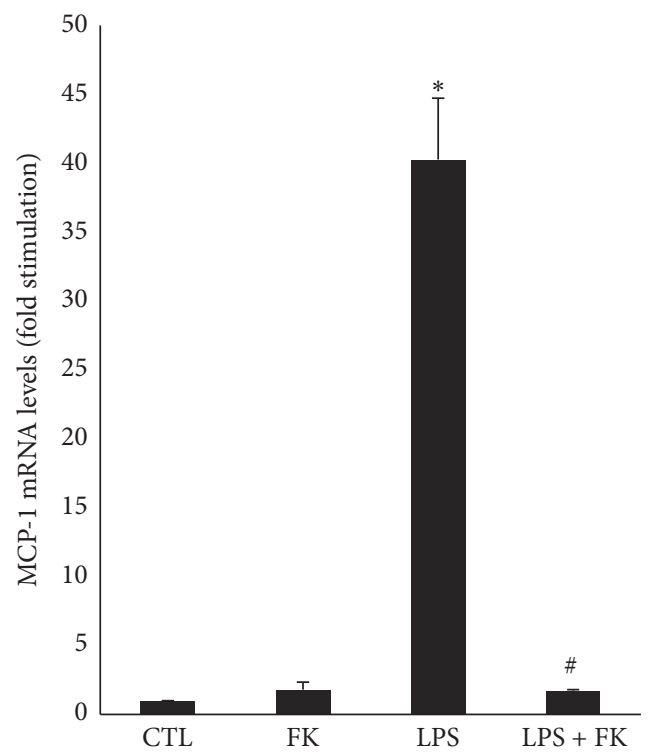

(a)

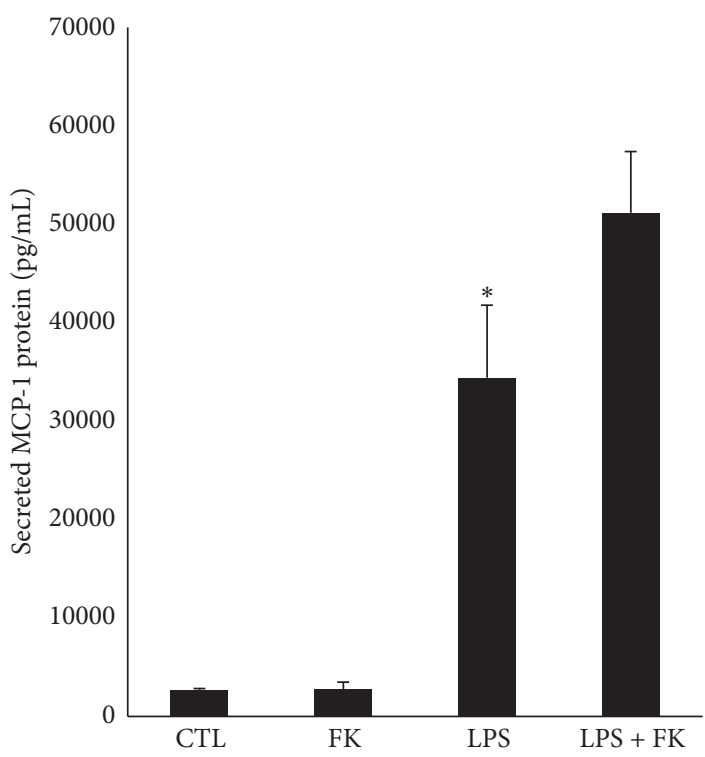

(b)

FIGURE 2: mRNA expression of MCP-1 (a) and MCP-1 protein secretion (b) in differentiated 3T3-L1 cells treated with LPS in the presence or absence of FK. Differentiated 3T3-L1 cells were treated as described in Materials and Methods under the following conditions: CTL, $10 \mu \mathrm{M}$ FK, $1 \mu \mathrm{g} / \mathrm{mL}$ LPS, and LPS + FK. (a) The results are expressed as mRNA levels (fold stimulation over CTL set to 1) and (b) secreted MCP-1 protein levels are the means \pm SEM of 3 independent experiments. Data were analyzed using $t$-test for unique sample and paired $t$-test; ${ }^{*} p<0.05$ versus CTL; $" p<0.05$ versus LPS.

\section{Discussion}

Obesity is strongly associated with increased risk of cardiovascular disorders. Recent studies have shown that increased levels of proinflammatory cytokines, including MCP-1, are involved in obesity and insulin resistance $[4,33]$ and that excess intake and endogenous release (lipolysis) of saturated fatty acids might enhance expression of TLR- 4 target genes including MCP-1. Indeed, TLR-4-deficient knockout mice fed with a diet rich in saturated fatty acid had lower macrophage infiltration and MCP-1 expression in their visceral adipose tissue as compared to wild-type mice [34]. LPS have been shown to stimulate secretion of inflammatory adipokines through activation of Toll-like receptor-4 (TLR-4) and the downstream transcription factor nuclear factor, $\mathrm{NF} \kappa \mathrm{B}$, in adipocytes [29-31]. In addition, Forskolin caused positive changes in body composition in overweight and obese adult men [21]. In the present study, we analyzed for the first time the effect of Forskolin on LPS-induced modulation of MCP-1, TLR-4, GPR120, $\beta$-Arrestin 2, and NF $\kappa$ B1 gene expression.

We confirmed that MCP-1 mRNA and proteins levels were increased following LPS treatment in 3T3-L1 cells differentiated into adipocytes and that this effect was mediated by TLR-4, as a TLR-4 inhibitor abolished the effect of LPS. Furthermore, we showed for the first time that Forskolin can inhibit the LPS-induced increase of MCP-1 mRNA level. Although MCP-1 protein levels were also increased in response to LPS, Forskolin did not significantly affect this LPS-induced increase in MCP-1 protein levels. Direct relationship between the mRNA and protein levels is not always observed, as the levels of both mRNA and proteins levels result from a ratio between synthesis and degradation. In addition, half-lives of proteins within cells vary widely from minutes to several days [35]. As both MCP-1 mRNA and secreted MCP-1 protein levels were not determined at similar times following cell treatment ( 4 hours for mRNA and 24 hours for proteins), distinct incubation times and the obvious distinct effects of FK on mRNA and protein halflives (i.e., affecting synthesis and/or degradation) are likely to account for the observed data. Further work will include kinetic studies to determine the half-lives of mRNA and protein.

Our data suggest that Forskolin might therefore represent an interesting approach to decrease inflammation related to obesity in adipose tissue. The signaling pathway involved in the inhibition of LPS-induced MCP-1 mRNA levels by Forskolin was also investigated. Toll-like receptors, expressed on virtually all human cells and binding a wide spectrum of exogenous and endogenous ligands such as bacterial LPS, are involved in metabolic disorders [36, 37]. Our result confirmed that LPS alone increased TLR- 4 mRNA levels in differentiated adipocytes and this increase was abolished by CLI095, a TLR-4 inhibitor. These data suggest a positive feedback loop between LPS and TLR-4. Furthermore, our data are in agreement with those showing that TLR- 4 knockout mice are protected against high-fat diet-induced obesity, inflammation, and insulin resistance and exhibited reduced insulin-mediated changes in systemic glucose metabolism [19]. Our data also show for the first time that Forskolin can inhibit LPS-induced increase in TLR-4 mRNA levels. These data clearly suggest that Forskolin could play a protective role in the inflammatory environment of adipose tissue. 


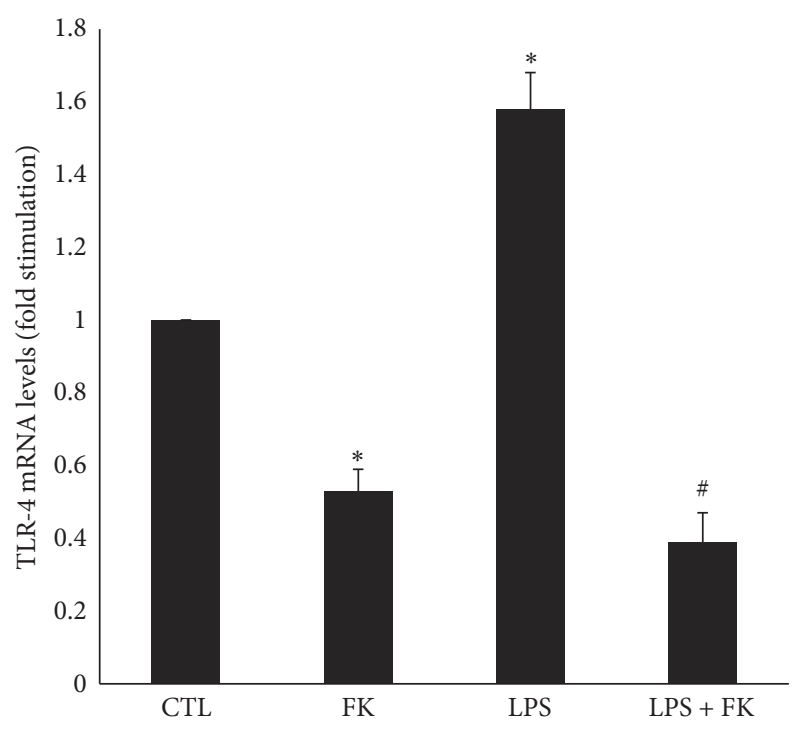

FIGURE 3: mRNA expression of TLR-4 in differentiated 3T3-L1 cells treated with LPS in the presence or absence of FK. Differentiated 3T3-L1 cells were treated as described in Materials and Methods under the following conditions: CTL, $10 \mu \mathrm{M}$ FK, $1 \mu \mathrm{g} / \mathrm{mL}$ LPS, and LPS + FK. The results are expressed as mRNA levels (fold stimulation over CTL set to 1 ) and are the means \pm SEM of 3 independent experiments. Data were analyzed using $t$-test for unique sample and paired $t$-test; ${ }^{*} p<0.05$ versus CTL; ${ }^{*} p<0.05$ versus LPS.

In addition, our study originally reported that Forskolin increased GPR120 mRNA level both in the absence and in the presence of LPS, that is, a proinflammatory cue. These data are particularly interesting as, in a macrophage cell line, DHA (a GPR120 agonist) antagonizes the proinflammatory effects of TNF- $\alpha$ and LPS and requires the presence of GPR120 to counteract the proinflammatory actions of LPS on cytokines' gene expression and protein secretion [14]. In the presence of LPS, DHA significantly decreased MCP-1 mRNA level but increased both $\beta$-Arrestin 2 and GPR120 mRNA levels [38]. The inhibitory effects of DHA on LPS-(TLR-4)-induced activation of NFkB activity might be mediated by a GPR120$\beta$-Arrestin 2-dependent mechanism [14]. We hypothesized that the effect of Forskolin on LPS-induced increase of MCP-1 mRNA level could involve a GPR120- $\beta$-Arrestin 2-dependent anti-inflammatory mechanism requiring $\mathrm{NF} \kappa \mathrm{B}$ activation via $\mathrm{I} \kappa \mathrm{B} \alpha$ degradation upon phosphorylation. Thereby, we examined the effect of an $\mathrm{I} \kappa \mathrm{B} \alpha$ inhibitor, BAY11-7082, on MCP1, GPR120, TLR-4, and NFאB1 mRNA levels. We observed that BAY11-7082 abolished the effect of LPS on MCP-1, GPR120, TLR-4, and NF $\kappa$ B1 mRNA levels; this confirmed the involvement of an $\mathrm{NF} \kappa \mathrm{B}$ pathway in the regulation of expression of these genes. In addition, our results showed that Forskolin alone or in the presence of LPS inhibits NF $\kappa$ B1 mRNA levels in DC. Furthermore, no change in both total and phosphorylated $\mathrm{I} \kappa \mathrm{B} \alpha$ protein levels could be detected by semiquantitative Western blot analysis upon adipocyte treatment with LPS and Forskolin alone or in combination. Recent reports have hypothesized that small increases in cytosolic concentrations of $\mathrm{I} \kappa \mathrm{B} \alpha$ negatively affect

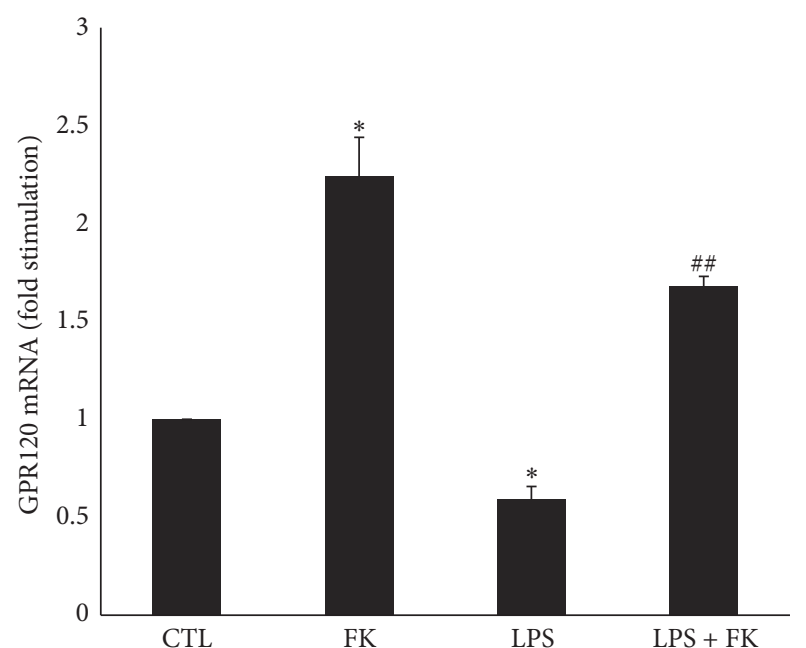

FIGURE 4: mRNA expression of GPR120 in differentiated 3T3-L1 cells treated with LPS in the presence or absence of FK. Differentiated 3T3-L1 cells were treated as described in Materials and Methods under the following conditions: CTL, $10 \mu \mathrm{M}$ FK, $1 \mu \mathrm{g} / \mathrm{mL}$ LPS, and LPS + FK. The results are expressed as mRNA levels (fold stimulation over CTL set to 1 ) and are the means \pm SEM of 3 independent experiments. Data were analyzed using $t$-test for unique sample and paired $t$-test; ${ }^{*} p<0.05$ versus CTL; ${ }^{\#} p<0.01$ versus LPS.

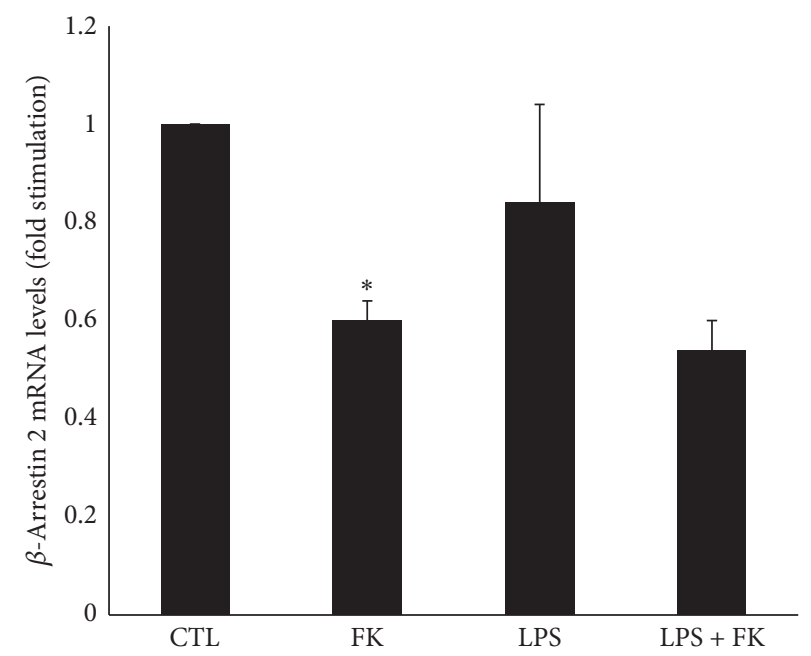

FIGURE 5: mRNA expression of $\beta$-Arrestin 2 in differentiated 3T3-L1 cells treated with LPS in the presence or absence of FK. Differentiated 3T3-L1 cells were treated as described in Materials and Methods under the following conditions: CTL, $10 \mu \mathrm{M}$ FK, $1 \mu \mathrm{g} / \mathrm{mL}$ LPS, and LPS + FK. The results are expressed as mRNA levels (fold stimulation over CTL set to 1 ) and are the means \pm SEM of 3 independent experiments. Data were analyzed using $t$-test for unique sample and paired $t$-test; ${ }^{*} p<0.05$ versus CTL.

$\mathrm{NF} \kappa \mathrm{B}$ nuclear translocation [32]. This hypothesis relies on the fact that only $10 \%$ of $\mathrm{NF} \kappa \mathrm{B}$ is translocated to the nucleus at a steady state. Therefore, even a 2 -fold increase in $\mathrm{I} \kappa \mathrm{B} \alpha$ protein concentration might be sufficient to retain the entire $\mathrm{NF} \kappa \mathrm{B}$ activity in the cytoplasm [32]. Other studies have shown that Forskolin inhibits $\mathrm{NF} \kappa \mathrm{B}$-mediated transcription 


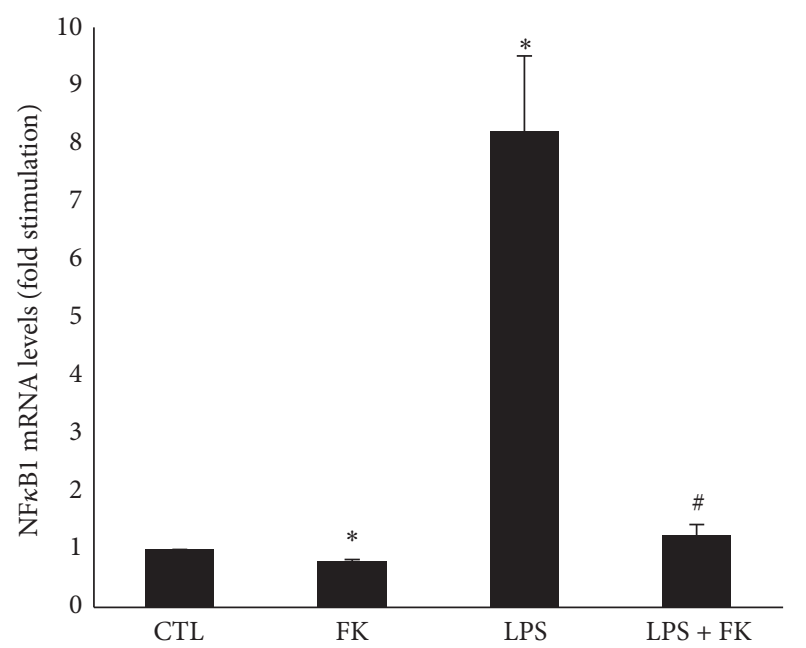

(a)

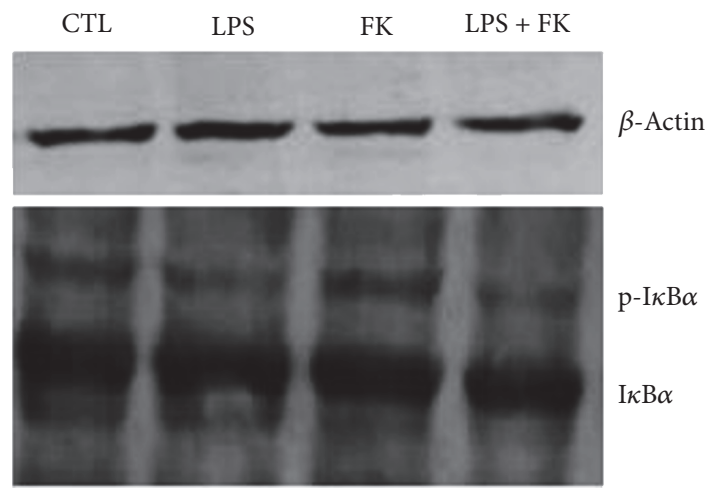

(b)

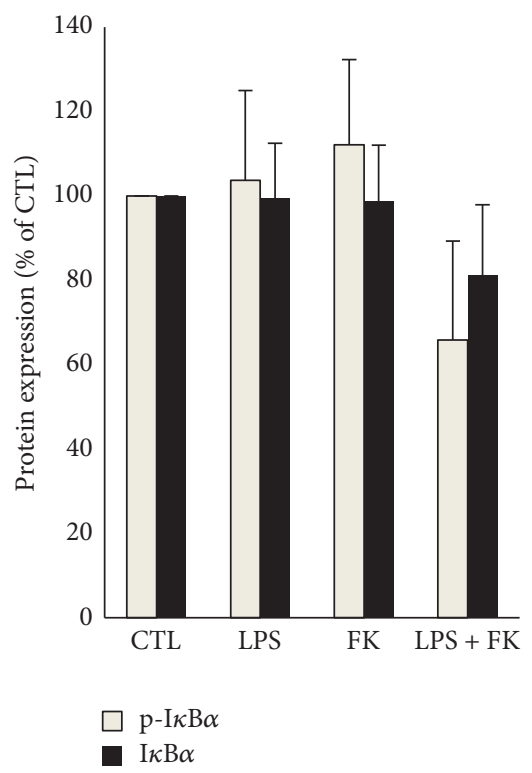

(c)

FIGURE 6: NF $\kappa$ B1 mRNA and I $\kappa \mathrm{B} \alpha$ protein levels in differentiated 3T3-L1 cells treated with LPS in the absence or presence of FK. Differentiated 3T3-L1 cells were treated as described in Materials and Methods under the following conditions: CTL, $10 \mu \mathrm{M} \mathrm{FK,} 1 \mu \mathrm{g} / \mathrm{mL}$ LPS, and LPS + FK. (a) The results are expressed as mRNA levels (fold stimulation over CTL set to 1). (b) Phospho-I $\kappa \mathrm{B} \alpha$ and total I $\kappa \mathrm{B} \alpha$ protein levels were determined in DC by Western blot analysis. (c) Semiquantitative determination of protein expression was performed as described under Materials and Methods. The results are expressed as protein expression (ratio of total $\mathrm{I} \kappa \mathrm{B} \alpha$ or P-I $\kappa \mathrm{B} \alpha$ band density over $\beta$-actin band density) expressed as percent of the CTL value (CTL set to $100 \%)$ and are the mean \pm SEM $(n=3)$ (in \% of CTL). Data were analyzed using $t$-test for unique sample and paired $t$-test; ${ }^{*} p<0.05$ versus CTL; ${ }^{*} p<0.05$ versus LPS.

of several genes and that various doses of Forskolin did not significantly reduce the proteolytic degradation of $\mathrm{I} \kappa \mathrm{B} \alpha$ in HUVEC and THP-1 cells [39]. On the contrary, Forskolin increased the cytoplasmic levels of $\mathrm{I} \kappa \mathrm{B} \alpha$ in Jurkat T-cells, which selectively decreases the nuclear translocation of p65 [40], while another report [41] has shown that $\beta$-agonists exert their anti-inflammatory effects by increasing the cytoplasmic concentrations of $\mathrm{I} \kappa \mathrm{B} \alpha$ in monocytic cells. It should be noted that these authors did not investigate the production of $\mathrm{I} \kappa \mathrm{B} \alpha$ at the same time points and in the same cell types. The free $\mathrm{I} \kappa \mathrm{B} \alpha$ has a short half-life in vivo [42, 43], supporting the idea that dissociation from NF-kB leads to rapid degradation of $\mathrm{I} \kappa \mathrm{B} \alpha$. In contrast to its remarkable stability when bound to $\mathrm{NF} \kappa \mathrm{B}$, free $\mathrm{I} \kappa \mathrm{B} \alpha$ is intrinsically very unstable, its half-life is $<10 \mathrm{~min}$, and it is rapidly degraded in a process that does not require phosphorylation or ubiquitination $[44,45]$. This rapid degradation of $\mathrm{I} \kappa \mathrm{B} \alpha$ could explain why, in our study, no changes in $\mathrm{I} \kappa \mathrm{B} \alpha$ protein levels (total and phosphorylated) could be detected following $24 \mathrm{~h}$ incubation with Forskolin in the absence or presence of LPS. Even if the effects of 


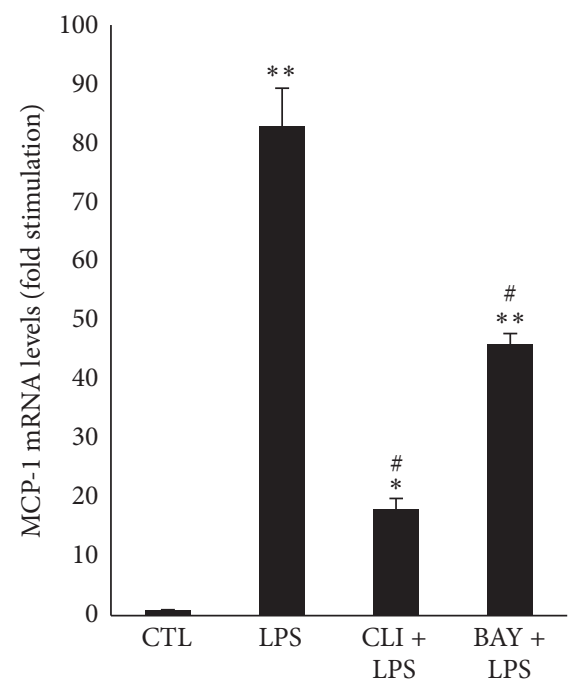

(a)

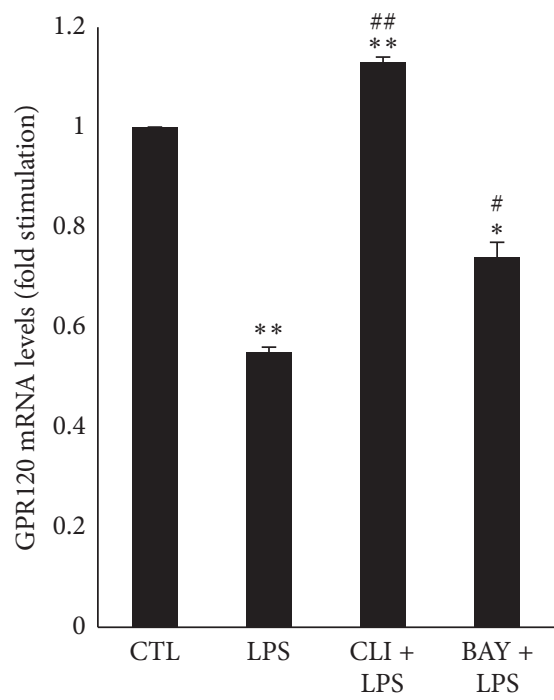

(c)

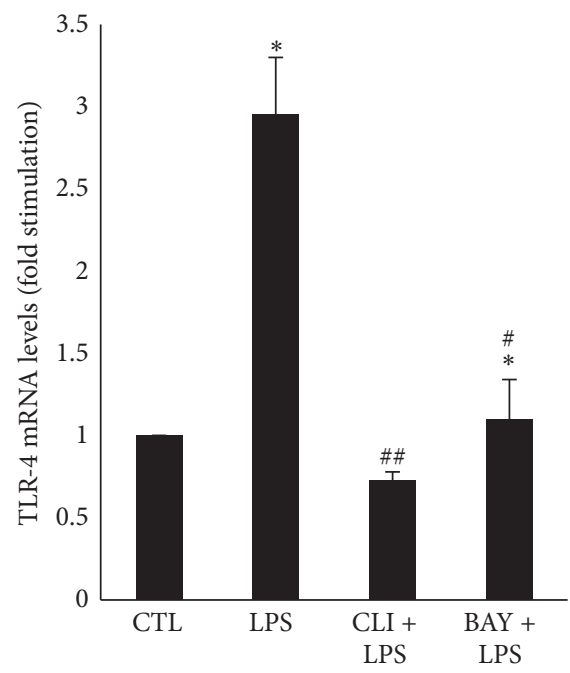

(b)

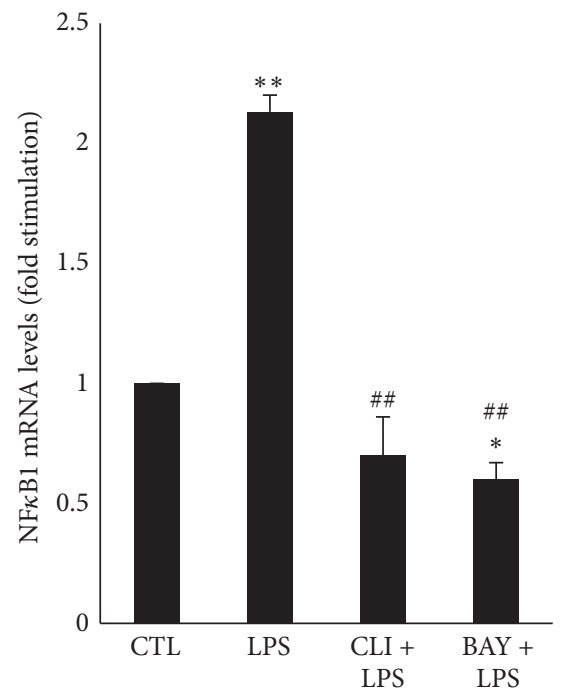

(d)

FIGURE 7: mRNA expression of MCP-1 (a), TLR-4 (b), GPR120 (c), and NFא B1 (d) in differentiated 3T3-L1 cells treated with LPS in the presence or absence of inhibitors. Differentiated 3T3-L1 cells were treated as described in Materials and Methods under the following conditions: CTL, $1 \mu \mathrm{g} / \mathrm{mL}$ LPS, $3 \mu \mathrm{M}$ CLI-095 $+1 \mu \mathrm{g} / \mathrm{mL}$ LPS (CLI + LPS), and $10 \mu \mathrm{M}$ of BAY11-7082 $+1 \mu \mathrm{g} / \mathrm{mL}$ LPS (BAY + LPS). The results are expressed as mRNA levels (fold stimulation over CTL set to 1 ) and are the means \pm SEM of 3 independent experiments. Data were analyzed using $t$-test for unique sample and paired $t$-test; ${ }^{*} p<0.05 ;{ }^{* *} p<0.01$ versus CTL; ${ }^{\#} p<0.05 ;{ }^{\# \#} p<0.01$ versus LPS.

Forskolin on the $\mathrm{I} \kappa \mathrm{B} \alpha$ protein level differ between studies [39-41], including ours, we showed that Forskolin exerts its anti-inflammatory effects by inhibiting the expression of $\mathrm{NF} \kappa \mathrm{B}$-dependent genes. In our study, we observed that LPS-induced increases in MCP-1, TLR-4, and NF $\kappa$ B mRNA levels were downregulated by Forskolin. On the other hand, GPR120 mRNA levels were upregulated in the presence of Forskolin. GPR120 plays an anti-inflammatory role by activating anti-inflammatory pathways [14]. Our data clearly reveal an interaction between $\mathrm{NF} \kappa \mathrm{B}$ and cAMP pathways in adipocytes as Forskolin exerts its anti-inflammatory role in adipocytes by inhibiting NF $\kappa \mathrm{B}-$ mediated gene transcription. Such inhibition could result from the binding competition between cAMP response element-binding protein (CREB) and $\mathrm{NF} \kappa \mathrm{B}$ to the coactivator CREB-binding protein (CBP), a protein necessary for efficient gene transcription [46]. Indeed, upon activation of the protein kinase A (PKA) pathway, increased phosphorylated CREB-CBP complexes will form, inducing an inhibition of $\mathrm{NF} \kappa \mathrm{B}$ (p65) [46]. PKA activation reduces the induction of a distinct set of genes in monocytes and endothelial cells by inhibiting $\mathrm{NF} \kappa \mathrm{B}-$ mediated gene transcription [47]. Therefore, to account for 


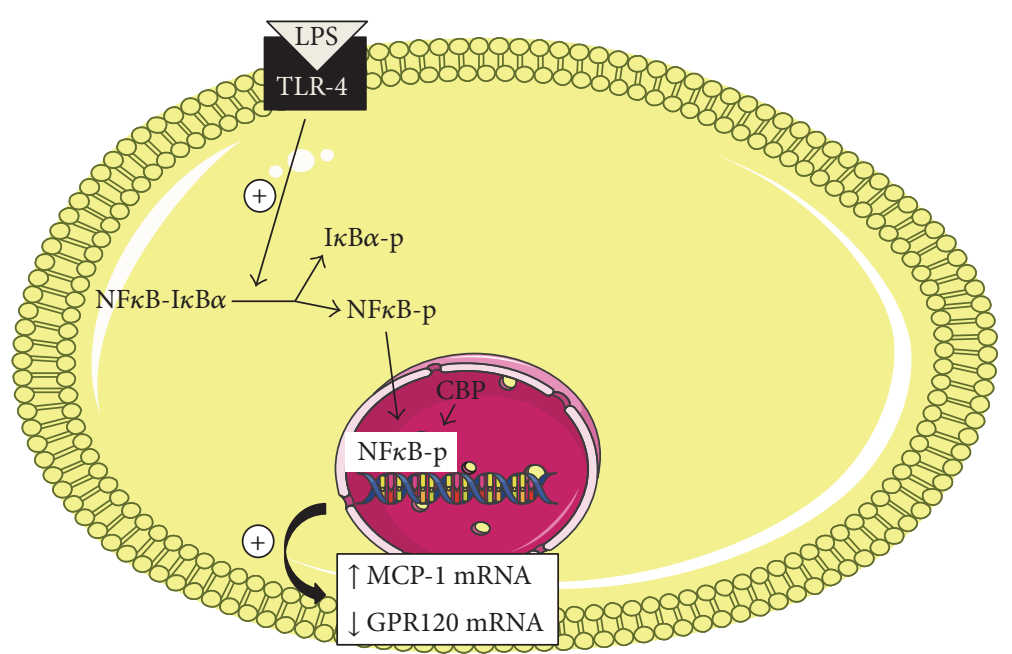

(a) Response to LPS

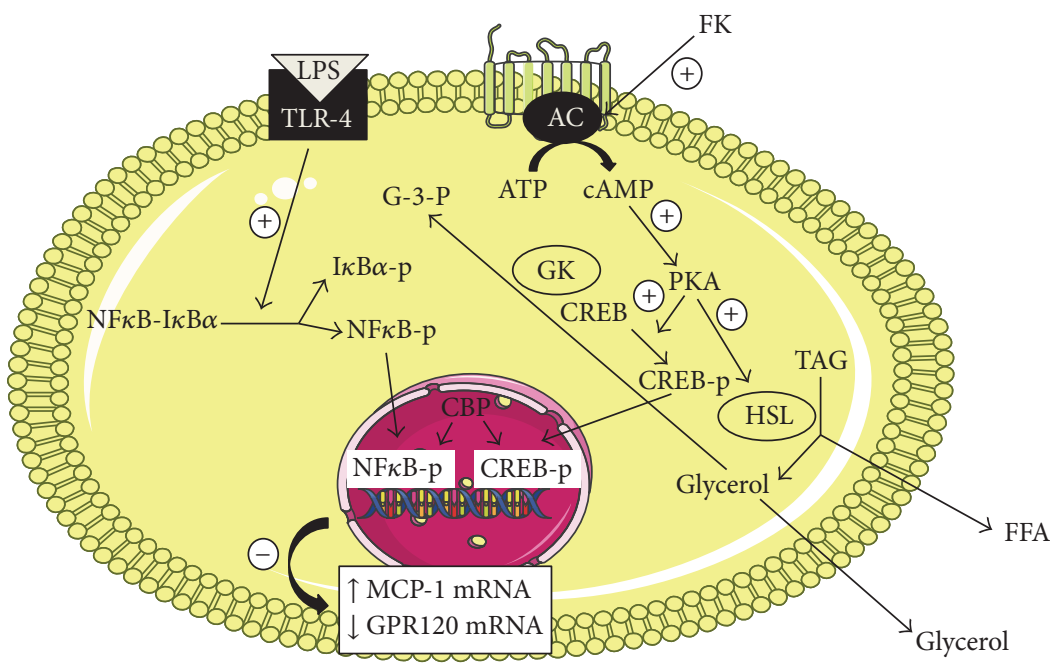

(b) Effect of FK on the LPS response

FIGURE 8: Data summary. (a) When adipocytes are stimulated with LPS, GPR120 mRNA levels are decreased, while MCP-1 mRNA and protein levels are upregulated via TLR-4 signaling pathway and NFאB activation. (b) When adipocytes are treated with LPS in the presence of FK, the LPS-induced effects on both MCP-1 and GPR120 are inhibited via PKA and CREB activation necessitating CBP binding. AC: adenylyl cyclase; ATP: adenosine triphosphate; cAMP: cyclic adenosine monophosphate; CBP: CREB-binding protein; CREB: cAMP response element-binding protein; FFA: free fatty acids; FK: Forskolin; G-3-P: glycerol-3-phosphate; GK: glycerol kinase; GPR120: G-protein coupled receptor 120; H: catecholamines or hormones; HSL: hormone sensitive lipase; $\mathrm{I} \kappa \mathrm{B} \alpha$ : inhibitor of kappa B; LPS: lipopolysaccharide; MCP-1: monocyte chemotactic protein-1; NF $\kappa$ B: nuclear factor- $\kappa$ B; p: phosphorylated; PKA: protein kinase A; TAG: triacylglycerol; TLR-4: Toll-like receptor 4 .

the data observed in our study, we hypothesize that Forskolin exerts its anti-inflammatory effects on LPS-induced modulation of $\mathrm{NF} \kappa \mathrm{B}$ target genes in adipocytes by increasing cAMP levels, PKA activity, CREB phosphorylation, and CREB interaction with CBP (Figure 8). Additional studies will be required to assess the involvement of PKA and CREB activation, as well as interaction between CBP, CREB, and $\mathrm{NF} \kappa \mathrm{B}$ in such process.

In conclusion, pharmacological agents that elevate intracellular levels of cAMP, such as Forskolin, may be useful for the treatment of inflammation associated with obesity.

\section{Competing Interests}

The authors declare that there are no competing interests regarding the publication of this article.

\section{Acknowledgments}

The authors thank Pierre Cullus for his statistical assistance and Violette Dirix for helpful discussion. This work was supported by grants from Van Buuren Fund and Defay Fund (Université Libre de Bruxelles). Jeanne Durendale 
Chiadak was a recipient of a Doctoral Fellowship from "Fonds Xénophilia" (Université Libre de Bruxelles) and a travel grant from the "Féderation Wallonie Bruxelles."

\section{References}

[1] E. E. Kershaw and J. S. Flier, "Adipose tissue as an endocrine organ," The Journal of Clinical Endocrinology \& Metabolism, vol. 89, no. 6, pp. 2548-2556, 2004.

[2] K. E. Wellen and G. S. Hotamisligil, "Obesity-induced inflammatory changes in adipose tissue," The Journal of Clinical Investigation, vol. 112, no. 12, pp. 1785-1788, 2003.

[3] S. P. Weisberg, D. McCann, M. Desai, M. Rosenbaum, R. L. Leibel, and A. W. Ferrante Jr., "Obesity is associated with macrophage accumulation in adipose tissue," Journal of Clinical Investigation, vol. 112, no. 12, pp. 1796-1808, 2003.

[4] H. Xu, G. T. Barnes, Q. Yang et al., "Chronic inflammation in fat plays a crucial role in the development of obesity-related insulin resistance," The Journal of Clinical Investigation, vol. 112, no. 12, pp. 1821-1830, 2003.

[5] K. Takahashi, S. Mizuarai, H. Araki et al., "Adiposity elevates plasma MCP-1 levels leading to the increased CD11b-positive monocytes in mice," The Journal of Biological Chemistry, vol. 278, no. 47, pp. 46654-46660, 2003.

[6] P. Sartipy and D. J. Loskutoff, "Monocyte chemoattractant protein 1 in obesity and insulin resistance," Proceedings of the National Academy of Sciences of the United States of America, vol. 100, no. 12, pp. 7265-7270, 2003.

[7] G. S. Hotamisligil, "Inflammation and metabolic disorders," Nature, vol. 444, no. 7121, pp. 860-867, 2006.

[8] S. E. Shoelson and A. B. Goldfine, "Getting away from glucose: fanning the flames of obesity-induced inflammation," Nature Medicine, vol. 15, no. 4, pp. 373-374, 2009.

[9] E. Manickam, A. J. Sinclair, and D. Cameron-Smith, "Suppressive actions of eicosapentaenoic acid on lipid droplet formation in 3T3-L1 adipocytes," Lipids in Health and Disease, vol. 9, article 57, 2010.

[10] A. Mullen, C. E. Loscher, and H. M. Roche, "Anti-inflammatory effects of EPA and DHA are dependent upon time and doseresponse elements associated with LPS stimulation in THP-1derived macrophages," Journal of Nutritional Biochemistry, vol. 21, no. 5, pp. 444-450, 2010.

[11] H. W. Hsueh, Z. Zhou, J. Whelan et al., "Stearidonic and eicosapentaenoic acids inhibit interleukin-6 expression in ob/ob mouse adipose stem cells via toll-like receptor-2-mediated pathways," Journal of Nutrition, vol. 141, no. 7, pp. 1260-1266, 2011.

[12] R. K. Murumalla, M. K. Gunasekaran, J. K. Padhan et al., "Fatty acids do not pay the toll: effect of SFA and PUFA on human adipose tissue and mature adipocytes inflammation," Lipids in Health and Disease, vol. 11, article 175, 2012.

[13] E. Oliver, F. C. McGillicuddy, K. A. Harford et al., "Docosahexaenoic acid attenuates macrophage-induced inflammation and improves insulin sensitivity in adipocytes-specific differential effects between LC n-3 PUFA," Journal of Nutritional Biochemistry, vol. 23, no. 9, pp. 1192-1200, 2012.

[14] D. Y. Oh, S. Talukdar, E. J. Bae et al., "GPR120 is an omega-3 fatty acid receptor mediating potent anti-inflammatory and insulinsensitizing effects," Cell, vol. 142, no. 5, pp. 687-698, 2010.

[15] R. L. Bradley, F. M. Fisher, and E. Maratos-Flier, "Dietary fatty acids differentially regulate production of TNF- $\alpha$ and IL-10 by murine 3T3-L1 adipocytes," Obesity, vol. 16, no. 5, pp. 938-944, 2008.

[16] C. YeopHan, A. Y. Kargi, M. Omer, C. K. Chan, M. Wabitsch, and K. D. O'Brien, "Differential effect of saturated and unsaturated free fatty acids on the generation of monocyte adhesion and chemotactic factors by adipocytes: dissociation of adipocyte hypertrophy from inflammation," Diabetes, vol. 59, no. 2, pp. 386-396, 2010.

[17] J. Zhang, L. S. Barak, K. E. Winkler, M. G. Caron, and S. S. G. Ferguson, "A central role for $\beta$-arrestins and clathrin-coated vesicle-mediated endocytosis in $\beta_{2}$-adrenergic receptor resensitization. Differential regulation of receptor resensitization in two distinct cell types," The Journal of Biological Chemistry, vol. 272, no. 43, pp. 27005-27014, 1997.

[18] H. Shi, M. V. Kokoeva, K. Inouye, I. Tzameli, H. Yin, and J. S. Flier, "TLR4 links innate immunity and fatty acid-induced insulin resistance," Journal of Clinical Investigation, vol. 116, no. 11, pp. 3015-3025, 2006.

[19] D. M. L. Tsukumo, M. A. Carvalho-Filho, J. B. C. Carvalheira et al., "Loss-of-function mutation in Toll-like receptor 4 prevents diet-induced obesity and insulin resistance," Diabetes, vol. 56, no. 8, pp. 1986-1998, 2007.

[20] T. A. McNicholas, J. D. Dean, H. Mulder, C. Carnegie, and N. A. Jones, "A novel testosterone gel formulation normalizes androgen levels in hypogonadal men, with improvements in body composition and sexual function," BJU International, vol. 91, no. 1, pp. 69-74, 2003.

[21] M. P. Godard, B. A. Johnson, and S. R. Richmond, "Body composition and hormonal adaptations associated with forskolin consumption in overweight and obese men," Obesity Research, vol. 13, no. 8, pp. 1335-1343, 2005.

[22] S. E. Atkinson, E. S. Maywood, J. E. Chesham et al., "Cyclic AMP signaling control of action potential firing rate and molecular circadian pacemaking in the suprachiasmatic nucleus," Journal of Biological Rhythms, vol. 26, no. 3, pp. 210-220, 2011.

[23] S. T. Ballard, L. Trout, J. Garrison, and S. K. Inglis, "Ionic mechanism of forskolin-induced liquid secretion by porcine bronchi," American Journal of Physiology-Lung Cellular and Molecular Physiology, vol. 290, no. 1, pp. L97-L104, 2006.

[24] J.-L. Cao, V. F. Vialou, M. K. Lobo et al., "Essential role of the cAMP-cAMP response-element binding protein pathway in opiate-induced homeostatic adaptations of locus coeruleus neurons," Proceedings of the National Academy of Sciences of the United States of America, vol. 107, no. 39, pp. 17011-17016, 2010.

[25] I. V. Sokolova, H. A. Lester, and N. Davidson, "Postsynaptic mechanisms are essential for forskolin-induced potentiation of synaptic transmission," Journal of Neurophysiology, vol. 95, no. 4, pp. 2570-2579, 2006.

[26] T. Arsenijevic, F. Grégoire, V. Delforge, C. Delporte, and J. Perret, "Murine 3T3-L1 Adipocyte cell differentiation model: validated reference genes for qPCR gene expression analysis," PLoS ONE, vol. 7, no. 5, Article ID e37517, 2012.

[27] T. Arsenijevic, F. Gregoire, J. Chiadak et al., "Pituitary Adenylate Cyclase Activating Peptide (PACAP) participates in adipogenesis by activating ERK signaling pathway," PLoS ONE, vol. 8, no. 9, Article ID e72607, 2013.

[28] J. Vandesompele, K. De Preter, F. Pattyn et al., "Accurate normalization of real-time quantitative RT-PCR data by geometric averaging of multiple internal control genes," Genome Biology, vol. 3, no. 7, 2002.

[29] K. M. Ajuwon and M. E. Spurlock, "Adiponectin inhibits LPS-induced NF- $\kappa$ B activation and IL- 6 production and 
increases PPAR $\gamma 2$ expression in adipocytes," American Journal of Physiology - Regulatory Integrative and Comparative Physiology, vol. 288, no. 5, pp. R1220-R1225, 2005.

[30] K. M. Ajuwon, W. Banz, and T. A. Winters, "Stimulation with Peptidoglycan induces interleukin 6 and TLR2 expression and a concomitant downregulation of expression of adiponectin receptors 1 and 2 in 3T3-L1 adipocytes," Journal of Inflammation, vol. 6, article 8, 2009.

[31] E. Zoico, U. Garbin, D. Olioso et al., "The effects of adiponectin on interleukin-6 and MCP-1 secretion in lipopolysaccharidetreated 3T3-L1 adipocytes: Role of the NF- $\kappa \mathrm{B}$ pathway," International Journal of Molecular Medicine, vol. 24, no. 6, pp. 847-851, 2009.

[32] S. Miyamoto, P. J. Chiao, and I. M. Verma, "Enhanced I $\kappa \mathrm{B} \alpha$ degradation is responsible for constitutive NF- $\kappa \mathrm{B}$ activity in mature murine B-cell lines," Molecular and Cellular Biology, vol. 14, no. 5, pp. 3276-3282, 1994.

[33] A. J. Alonso-Castro, R. Zapata-Bustos, G. Goḿez-Espinoza, and L. A. Salazar-Olivo, "Isoorientin reverts TNF- $\alpha$-induced insulin resistance in adipocytes activating the insulin signaling pathway," Endocrinology, vol. 153, no. 11, pp. 5222-5230, 2012.

[34] J. E. Davis, N. K. Gabler, J. Walker-Daniels, and M. E. Spurlock, "Tlr-4 deficiency selectively protects against obesity induced by diets high in saturated fat," Obesity, vol. 16, no. 6, pp. 1248-1255, 2008.

[35] G. M. Cooper, "Protein degradation," in The Cell: A Molecular Approach, Sinauer Associates, Sunderland, Mass, USA, 2nd edition, 2000.

[36] K. Eguchi, I. Manabe, Y. Oishi-Tanaka et al., "Saturated fatty acid and TLR signaling link $\beta$ cell dysfunction and islet inflammation," Cell Metabolism, vol. 15, no. 4, pp. 518-533, 2012.

[37] K. Takeda, T. Kaisho, and S. Akira, “Toll-like receptors," Annual Review of Immunology, vol. 21, pp. 335-376, 2003.

[38] M. M. Cranmer-Byng, D. M. Liddle, A. A. De Boer, J. M. Monk, and L. E. Robinson, "Proinflammatory effects of arachidonic acid in a lipopolysaccharide-induced inflammatory microenvironment in 3T3-L1 adipocytes in vitro," Applied Physiology, Nutrition, and Metabolism, vol. 40, no. 2, pp. 142-154, 2015.

[39] P. Ghersa, R. H. Van Huijsduijnen, J. Whelan, Y. Cambet, R. Pescini, and J. F. DeLamarter, "Inhibition of E-selectin gene transcription through a cAMP-dependent protein kinase pathway," Journal of Biological Chemistry, vol. 269, no. 46, pp. 29129-29137, 1994.

[40] M. Neumann, T. Grieshammer, S. Chuvpilo et al., "RelA/p65 is a molecular target for the immunosuppressive action of protein kinase A," EMBO Journal, vol. 14, no. 9, pp. 1991-2004, 1995.

[41] P. Farmer and J. Pugin, "Beta-adrenergic agonists exert their 'anti-inflammatory' effects in monocytic cells through the IkappaB/NF-kappaB pathway," American Journal of Physiology_Lung Cellular and Molecular Physiology, vol. 279, no. 4, pp. L675-L682, 2000.

[42] S. Ghosh and D. Baltimore, "Activation in vitro of NF- $\kappa$ B by phosphorylation of its inhibitor I $\kappa$ B," Nature, vol. 344, no. 6267, pp. 678-682, 1990.

[43] S.-C. Sun, P. A. Ganchi, D. W. Ballard, and W. C. Greene, "NF- $\kappa$ b controls expression of inhibitor $\mathrm{i} \kappa \mathrm{B} \alpha$ : evidence for an inducible autoregulatory pathway," Science, vol. 259, no. 5103, pp. 19121915, 1993.

[44] D. Krappmann, F. G. Wulczyn, and C. Scheidereit, "Different mechanisms control signal-induced degradation and basal turnover of the NF- $\kappa \mathrm{B}$ inhibitor $\mathrm{I} \kappa \mathrm{B} \alpha$ in vivo," EMBO Journal, vol. 15, no. 23, pp. 6716-6726, 1996.
[45] E. Mathes, E. L. O’Dea, A. Hoffmann, and G. Ghosh, "NF- $\kappa$ B dictates the degradation pathway of $\mathrm{I} \kappa \mathrm{B} \alpha$," The EMBO Journal, vol. 27, no. 9, pp. 1357-1367, 2008.

[46] G. C. N. Parry and N. Mackman, "role of cyclic AMP response element-binding protein in cyclic AMP inhibition of NF- $\kappa \mathrm{B}-$ mediated transcription," Journal of Immunology, vol. 159, no. 11, pp. 5450-5456, 1997.

[47] V. Ollivier, G. C. Parry, R. R. Cobb, D. de Prost, and N. Mackman, "Elevated cyclic AMP inhibits NF- $\kappa$ B-mediated transcription in human monocytic cells and endothelial cells," Journal of Biological Chemistry, vol. 271, no. 34, pp. 2082820835, 1996. 


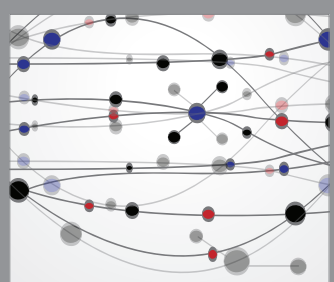

The Scientific World Journal
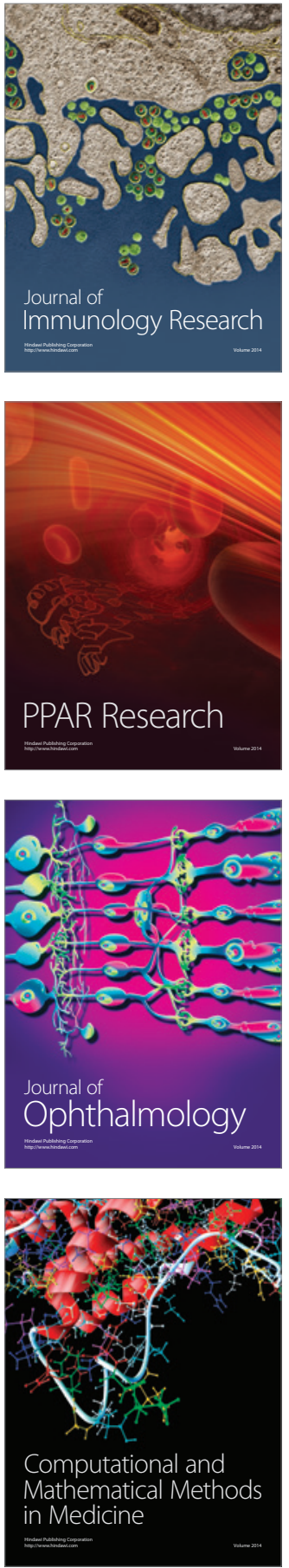

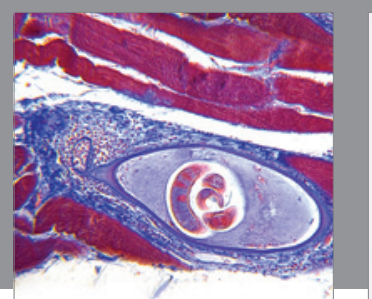

Gastroenterology Research and Practice

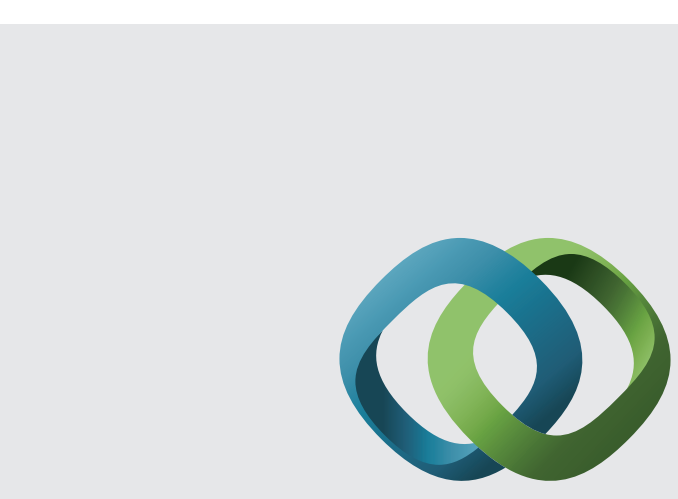

\section{Hindawi}

Submit your manuscripts at

http://www.hindawi.com
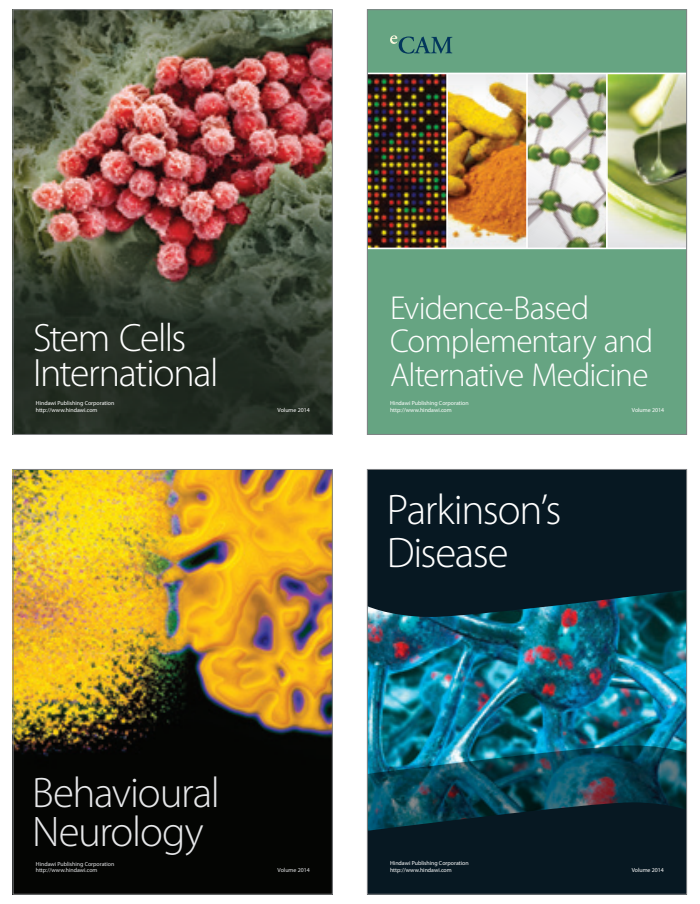
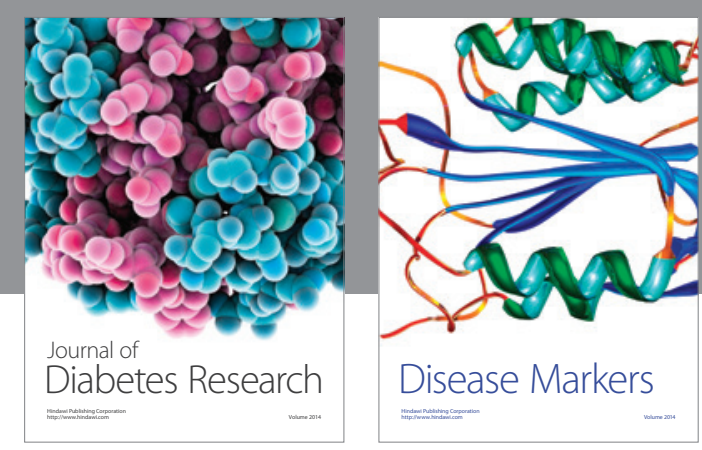

Disease Markers
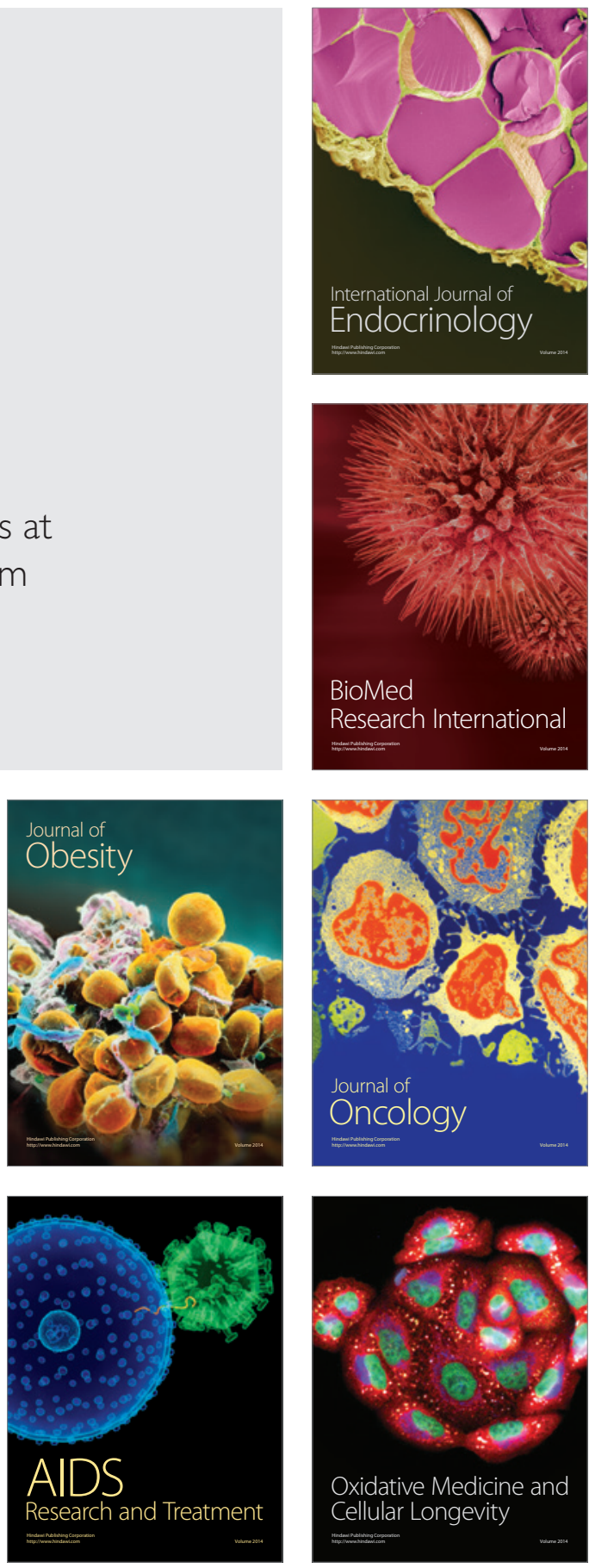